\title{
Peningkatan Kemampuan Menulis Teks Berita Melalui Penerapan Model Problem Based Learning Dengan Teknik Pengamatan Objek Langsung
}

\section{Helvita Sari Tarigan*}

${ }^{1}$ Program Studi Bahasa dan Sastra Indonesia, FBS Universitas Pendidikan Ganesha

ARTICLE INFO

Article history:

Received January 21, 2021

Revised February 03, 2021

Accepted April 08, 2021

Available online May 25, 2021

Kata Kunci:

Model problem based

learning, teknik pengamatan

objek langsung, kemampuan

menulis teks berita

Keywords:

problem based learning

model, direct object

observation technique, ability

to write news text.

\section{A B S T R A K}

Penelitian ini merupakan penelitian tindakan kelas (Class Action Reseach) yang bertujuan untuk mengetahui dan mendeskripsikan peningkatan keterampilan menulis teks berita siswa kelas XII MIPA 4 SMA Negeri 2 Singaraja melalui penerapan model problem based learning (PBL) dengan teknik pengamatan objek langsung. Penelitian ini terdiri atas dua siklus dan setiap siklus dilakukan dalam dua kali pertemuan. Subjek penelitian ini adalah siswa XII MIPA 4 SMA Negeri 2 Singaraja, sebanyak 29 orang. Hasil penelitian menunjukkan bahwa penerapan model problem based learning (PBL) dibantu teknik pengamatan objek langsung dapat meningkatkan keterampilan menulis teka berita. Peningkatan skor rata-rata keterampilan menulis berita adalah sebesar 9,7, yaitu dari rata-rata 68,6 menjadi 78,3. Jadi, pembelajaran dapat dikatakan berhasil karena secara keseluruhan siswa tuntas. Siswa juga memberikan respons yang sangat positif dalam mengikuti pembelajaran menulis teks berita melalui penerapan model problem based learning (PBL) dibantu teknik pengamatan objek langsung yakni dengan skor 55,2.

\section{A B S T RA C T}

This research is a class action research (Class Action Research) which aims to find out and describe the improvement of news text writing skills for students of class XII MIPA 4 SMA Negeri 2 Singaraja through the application of problem based learning (PBL) models with direct object observation techniques. This research consisted of two cycles and each cycle was conducted in two meetings. The subjects of this study were students of XII MIPA 4 SMA Negeri 2 Singaraja, as many as 29 people. The results showed that the application of the problem based learning (PBL) model assisted by direct object observation techniques could improve the skills of writing news riddles. The increase in the average score of news writing skills was 9.7, from an average of 68.6 to 78.3. So, learning can be said to be successful because overall students are complete. Students also gave very positive responses in participating in learning to write news texts through the application of problem based learning (PBL) models assisted by direct object observation techniques with a score of 55.2 .

\section{Pendahuluan}

Teori pendidikan merupakan landasan dan pijakan awal dalam pengembangan praktik pendidikan, misalnya pengembangan kurikulum, manajemen sekolah dan proses belajar mengajar. Kurikulum dan pembelajaran memiliki keterkaitan dengan teori pendidikan atau dalam penyusunan suatu kurikulum dan rencana pembelajaran ini mengacu pada teori pendidikan (Sholichah, 2018). Keterampilan berbahasa tidak dapat diperoleh melalui kegiatan menghafal. Keterampilan berbahasa bukanlah sesuatu yang dapat diajarkan melalui uraian atau penjelasan semata. Mahasiswa tidak dapat memperoleh keterampilan berbahasa hanya dengan duduk dan mendengar keterangan atau penjelasan dari pendidik. Keterampilan berbahasa dapat diperoleh dengan melakukan kegiatan berbahasa secara terus menerus (Nisa, 2017)Literasi Indonesia masih jauh tertinggal dibandingkan dengan negara-negara lain di seluruh dunia. Pada tahun 2011, data dari International Results in Reading (PIRLS) menunjukkan bahwa Indonesia menduduki posisi 45 dari 48 negara yang menjadi peserta (Faizah dkk. 2016). Pada tahun 2012, data Programme for International Student Assesment (PISA) menunjukkan bahwa Indonesia menduduki peringkat 64 dari 65 negara yang diteliti (OECD, 2013). Sedangkan pada tahun 2016, studi World Most Literate Countries yang dilakukan oleh Presiden Central Connecticut State University (CCSU) menunjukkan bahwa Indonesia berada di peringkat 60 dari 61 negara (Ninawati, 2019).

Pendidikan merupakan usaha sadar dan terencana untuk mewujudkan suasana belajar dan proses pembelajaran agar peserta didik secara aktif mengembangkan potensi dirinya untuk memiliki kekuatan spiritual keagamaan, pengendalian diri, kepribadian, kecerdasan, akhlak mulia serta keterampilan yang diperlukan untuk dirinya, masyarakat, bangsa dan Negara (Azwar, 2005). Pembelajaran bahasa di Sekolah Dasar umumnya menekankan kepada kemampuan siswa dalam menggunakan Bahasa Indonesia dengan

Copyright (c) Universitas Pendidikan Ganesha. All rights reserved. 
baik secara lisan maupun tulisan. Sehingga guru haruslah sudah paham dan mengerti bahwa pembelajaran bahasa Indonesia itu menggunakan pembelajaran yang menekankan pada pendekatan komunikatif. Pendekatan komunikatif, artinya dalam implementasinya pembelajaran bahasa Indonesia harus lebih menekankan pada aspek komunikatif dan fungsional. Hal yang terpenting dan harus diajarkan ialah bahasa sebagai alat komunikasi. Siswa diajak belajar berbahasa secara komunikatif untuk bekal kecakapan hidupnya sehingga bahasa merupakan sesuatu yang fungsional bagi kehidupannya (Nuryamah, Sunarya and Irawati, 2016).

Bahasa Adalah Simbol Lisan Yang Arbiter Yang Dipakai Oleh Suatu Anggota Masyarakat Untuk Berinteraksi Dan Berkomunikasi Dengan Sesamanya. Selanjutnya Chaer Mennyatakan Bahwa Bahasa Sebuah Sistem Yang Dibangun Oleh Sejumlah Subsistem (Fuad and Helminsyah, 2018). Keterampilan menulis mempunyai peranan yang sangat penting dalam kehidupan sehari-hari. Keterampilan menulis merupakan syarat untuk berkecimpung dalam berbagai macam bidang atau kegiatan. Hal ini mengandung pengertian betapa pentingnya keterampilan dan kemampuan menulis dalam kehidupan sehari-hari. Menulis juga merupakan salah satu keterampilan berbahasa yang dipergunakan dalam komunikasi secara tidak langsung. Melalui kegiatan menulis, siswa diarahkan mampu berkomunikasi dengan menggunakan bahasa tulis. Dalam hal ini, diharapkan siswa mampu menuangkan gagasan atau idenya secara runtut dengan diksinya yang tepat, struktur yang benar sesuai dengan konteksnya.Dalam pembelajaran menulis, salah satu kompetensi dasar yang akan dikaji oleh peneliti adalah kegiatan menulis kembali dongeng pada aspek kesusastraan. Kompetensi dasar tersebut yang harus ditempuh oleh siswa kelas VII semester I untuk mencapai salah satu tujuan pembelajaran. Melalui standar (Puspitasari and Rustono, 2014). kompetensi tersebut siswa diharuskan untuk mampu mengubah dongeng yang pernah dibaca dengan cara menulisnya kembali sesuai dengan bahasanya sendiri. Kegiatan penerjemahan merupakan keterampilan yang sulit. Penguasaan terhadap bahasa Inggris saja sebagai Bsu atau bahasa Indonesia sebagai BSa tidak menjamin keandalan atau keterpercayaan terjemahan yang dihasilkan. Perbedaan gramatika dari kedua bahasa ini jika tidak dikuasai secara baik tentu saja akan mengakibatkan kesalahan (Nisa, 2017).

Pentingnya pembelajaran menulis terlihat pada penerapan Kurikulum 2013 saat ini yang lebih menekankan pada aspek keterampilan menulis. Hal ini terlihat pada KD keterampilan 4.2 yang menekankan bahwa para siswa harus mampu menulis sesuai dengan struktur dan ciri kebahasaan yang terdapat dalam teks. Salah satu pembelajaran menulis nonsastra pada kurikulum 2013 di tingkat SMA adalah keterampilan menulis teks berita. Siregar dkk (1998: 18) mengemukakan bahwa kegiatan menulis berita adalah kegiatan yang melaporkan seluk beluk suatu peristiwa yang telah, sedang, atau akan terjadi. Dengan kata lain, berita yang ditulis merupakan rekontruksi tertulis atas apa yang terjadi. Berdasarkan tanggapan Siregar maka dapat dikatakan bahwa dengan menulis teks berita siswa diharapkan akan menjadi tanggap dan peka terhadap kondisi dan situasi lingkungan di sekitarnya.

Menulis berita bukanlah pekerjaan yang mudah, untuk itu diperlukan beberapa persiapan. Pertama, mengumpulkan informasi yang akan ditulis. Kedua, menulis informasi-informasi yang sudah dikumpulkan. Ketiga, menulis ulang informasi-informasi itu dengan merangkai menggunakan bahasabahasa yang mudah dimengerti dan dipahami oleh pembaca. Keempat, menyempurnakan kembali berita yang sudah ditulis sebelumnya. Disamping itu, dalam menulis teks berita harus memperhatikan penerapan kaidah bahasa Indonesia baku, seperti keefektifan kalimat, dan penerapan EYD yang tepat. Dengan memperhatikan kaidah-kaidah dalam menulis berita, informasi yang disampaikan diharapkan akan membantu pembaca untuk mudah mengerti isi dari teks berita.

Namun, kenyataan di lapangan menunjukan bahwa kemampuan siswa dalam kegiatan keterampilan menulis teks berita masih sangat rendah. Hal ini ditunjukan dari hasil observasi yang dilakukan di SMA Negeri 2 Singaraja, Informasi awal yang diperoleh menunjukkan bahwa, nilai rata-rata siswa dalam menulis teks berita masih di bawah KKM yakni 65, sedangkan KKM mata pelajaran bahasa Indonesia di kelas XII adalah 68. Hal tersebut menandakan bahwa ketuntasan pembelajaran teks berita masih belum tercapai. Berdasarkan hasil pengamatan serta wawancara terhadap siswa maupun guru bidang studi bahasa Indonesia di SMA Negeri 2 Singaraja, maka dapat ditarik kesimpulan mengenai faktor-faktor yang menjadi penyebab rendahnya kemampuan siswa dalam menulis teks berita antara lain. Pertama, keterampilan menulis kurang mendapat perhatian dan sering kali dianggap remeh oleh siswa. Menurut para siswa, setiap orang pasti bisa menulis dan keterampilan menulis tidak perlu diberikan secara khusus. Kedua, kurangnya konsentrasi dan antusias siswa ketika pembelajaran menulis berlangsung. Hanya beberapa siswa yang kelihatan antusias yang mana siswa yang antusias ini merupakan siswa yang memiliki bakat serta minat dalam kegiatan tulis menulis. Banyaknya siswa yang kurang antusias terhadap pembelajaran menulis dikarenakan anggapan siswa yang merasa kurang mendapat manfaat yang berarti dalam pembelajaran menulis dan menganggap remeh pelajaran bahasa Indonesia. Guru jarang memanfaatkan media yang lain selain papan tulis dan buku teks. Ketiga, Siswa kesulitan menuliskan isi teks berita sesuai dengan struktur dan unsur kebahasaan teks berita. Keempat, 
anggapan siswa bahwa pembelajaran berita sangat membosankan. Kelima, keenganan siswa dalam bertanya terhadap materi yang kurang dimengerti. Keenam, Guru kurang maksimal memanfaatkan berbagai model dan teknik pembelajaran yang ditawarkan pada kurikulum 2013.

Untuk mengatasi masalah-masalah yang dikemukakan di atas, diperlukan sebuah model yang tepat terhadap kemampun menulis teks berita. Salah satu model yang dapat diterapkan adalah model PBL (problem based learning) dengan teknik pengamatan objek langsung. Dipilihnya model PBL dengan teknik pengamatan objek langsung ini dikarenakan tiga alasan. Pertama, model ini menuntut aktivitas mental siswa. Hal ini disebabkan karena model ini mengharuskan tiap-tiap siswa untuk memahami suatu konsep pembelajaran melalui situasi dan masalah yang disajikan pada awal pembelajaran dengan tujuan untuk melatih siswa menyelesaikan masalah dengan menggunakan pendekatan pemecahan masalah. Kedua, model ini menekankan keterlibatan siswa secara penuh. Siswa berkedudukan sebagai subjek belajar dan guru hanya sebagai pemandu atau fasilitator. Ketiga, model ini menekankan kolaborasi dan kerjasama tim. Siswa yang dibentuk dalam kelompok kecil membuat para siswa saling bantu untuk memecahkan permasalahan yang diberikan. Penggunaan model Aplikasi dari model PBL yaitu dengan penggunaan teknik pengamatan objek langsung. Teknik pengamatan objek langsung merupakan teknik yang mengharuskan siswa untuk terjun langsung mengamati objek yang akan dijadikan berita. Siswa diberi kesempatan untuk keluar kelas dengan tujuan untuk mencari informasi serta wawancara secara langsung sesuai dengan tema yang mereka dapatkan. Melalui pengamatan objek secara langsung ini, diharapkan siswa akan lebih termotivasi untuk mengikuti pembelajaran. Dengan adanya motivasi dan semangat yang tinggi, maka siswa diharapkan mampu menuliskan secara ulang berita yang disajikan dengan singkat, padat dan jelas.

Penggunaan model PBL dan teknik pengamatan objek langsung merupakan suatu proses pembelajaran yang menarik karena selama ini proses pembelajaran yang berlangsung banyak dilakukan di ruangan kelas dan cenderung membuat siswa merasa jenuh. Selain itu, proses pembelajaran selama ini lebih banyak bersifat teoretis dibandingkan praktik dengan menggunakan model PBL dan teknik pengamatan objek langsung siswa dapat langsung terjun mencari jawaban atas permasalahan yang mereka temukan. Hal ini membuat siswa lebih aktif dan cepat memahami pembelajaran. Selain memiliki kelebihan, model PBL dengan teknik pengamatan objek langsung juga memiliki kelemahan, yaitu siswa kurang tertib jika tidak diawasi. Para siswa bisa menyalahgunakan waktu yang seharusnya digunakan untuk melakukan pengamatan berubah menjadi ajang bermain bagi mereka. Untuk mencegah hal tersebut, guru diharuskan bisa mengawasi semua siswa dan meyakinkan mereka bahwa keseriusan yang mereka berikan dalam pelajaran ini akan sangat bermanfaat bagi masa depan mereka.

Berdasarkan uraian permasalahan di atas atas dan alternatif solusi yang ditawarkan maka dibuatlah sebuah proposal penelitian dengan judul Peningkatan Kemampuan Menulis Teks Berita Melalui Penerapan Model Problem Based Learning dengan Teknik Pengamatan Objek Langsung pada Siswa Kelas XII SMA Negeri 2 Singaraja. Penelitian ini bertujuan untuk melihat peningkatan kemampuan siswa menulis teks berita dengan penerapaan model PBL menggunakan teknik pengamatan objek langsung.

\section{Metode}

\section{Rancangan Penelitian}

Penelitian ini menggunakan rancangan penelitian tindakan kelas (Classroom Action Research). Wendra (2007: 102) bahwa PTK merupakan penelitian yang dilakukan di kelas melalui tindakan tertentu dalam rangka memecahkan masalah yang sedang dihadapi oleh peneliti dalam pembelajaran. PTK dilakukan dalam beberapa siklus untuk memperoleh tindakan terbaik atau peningkatan yang diharapkan dapat tercapai.

Proses PTK ini direncanakan berlangsung dalam dua siklus. Tiap siklus terdiri atas empat tahap, yaitu: perencanaan, tindakan, observasi atau pengamatan, dan refleksi. Jika pada siklus I nilai rata-rata siswa belum mencapai target yang telah ditentukan, maka akan dilakukan tindakan siklus II. Namun, jika rancangan dalam dua siklus tidak tercapai dengan kata lain tindakan pada siklus II belum mencapai target yang telah ditentukan maka peneliti akan melangsungkan siklus III.

\section{Hasil Dan Pembahasan}

Penelitian ini dilaksanakan di SMA Negeri 2 Singaraja yang beralamat di jalan Jl. Srikandi Desa Baktiseraga, Kecamatan Buleleng, Kabupaten Buleleng, Bali. Penelitian tindakan kelas ini dilaksanakan pada semester ganjil pada siswa kelas XII MIPA 4 SMA Negeri 2 Singaraja tahun ajaran 2017/ 2018 yang berjumlah 29 orang siswa. Berdasarkan hasil pengamatan atau observasi yang dilakukan selama siklus I ditemukan beberapa kendala, antara lain terlalu banyaknya anggota kelompok sehingga terdapat beberapa siswa yang terlihat bermain dan tidak serius, kurangnya waktu menulis teks berita serta pengamatan objek langsung dikarenakan diintrupsi dengan bel istirahat, siswa terlalu fokus membuat 
kerangka teks berita sehingga tidak sempat menyusun kerangka tersebut menjadi sebuah teks berita yang utuh, siswa masih melakukan kesalahan penulisan ejaan dan tanda baca saat menulis teks berita; dan penjelasan dari guru masih kurang optimal. Berdasarkan permasalahan tersebut, maka diambil tindakan perbaikan pada siklus II antara lain: pembagian kelompok akan dipotong menjadi masing-masing kelompok terdiri dari 3 orang. Selain itu, dari masing-masing kelompok akan dipilih leader (ketua kelompok) agar kelompok terkoordinasi dengan baik, mengelola waktu pembelajaran lebih baik lagi sehingga kegiatan pembelajaran dapat berjalan sesuai dengan rencana yang telah disusun, menekankan pentingnya manfaat pembelajaran menulis teks berita bagi masa depan siswa sehingga siswa termotivasi untuk terus berlatih meningkatkan kualitas dalam menulis teks berita, memberikan bimbingan kepada siswa yang masih kesulitan dan salah dalam menggunakan unsur kebahasaan dan ejaan pada teks yang dibuatnya, dan guru memberikan penjelasan lebih rinci kepada siswa.

Selain itu, berdasarkan hasil analisis tes pada siklus I didapati masih banyak siswa yang belum tuntas. Ketidaktuntasan yang didapati pada siklus I akhirnya diperbaiki pada siklus ke II yang terlihat pada tabel berikut ini.

Tabel 1 . Perbandingan Skor Menulis Teks Berita dengan Menerapkan Model Pembelajaran PBL dengan teknik pengamatan objek langsung pada Siklus I dan Siklus II.

\begin{tabular}{|c|c|c|c|c|}
\hline No & Nama Siswa & $\begin{array}{c}\text { Skor } \\
\text { Siklus I }\end{array}$ & $\begin{array}{c}\text { Skor Siklus } \\
\text { II }\end{array}$ & KET \\
\hline 1 & Adi Prayoga Utama Dewa Gede & 66 & 81 & Meningkat \\
\hline 2 & Adi Putrayasa Komang & 74 & 83 & Meningkat \\
\hline 3 & Adi Sudhira Nyoman & 64 & 78 & Meningkat \\
\hline 4 & Adi Adi Sugianandra Ida Bagus & 71 & 80 & Meningkat \\
\hline 5 & Agus Prananta Kadek & 48 & 73 & Meningkat \\
\hline 6 & Anik Krisma Dewi Ni Kadek & 81 & 85 & Meningkat \\
\hline 7 & Ayu Indah Sari Ni Desak Ketut & 88 & 93 & Meningkat \\
\hline 8 & Ayu Novi Ardaningsih Luh & 71 & 78 & Meningkat \\
\hline 9 & Dendy Septian I Komang & 66 & 71 & Meningkat \\
\hline 10 & Devi Mediawadi Ni Kadek & 83 & 83 & Tetap \\
\hline 11 & Devi Sukma Nuryanti Luh Putu & 61 & 71 & Meningkat \\
\hline 12 & Devi Widyasari Ni Luh & 83 & 88 & Meningkat \\
\hline 13 & Dinda Dwi Putri & 68 & 83 & Meningkat \\
\hline 14 & Dhea Serly Selviyanti & 78 & 83 & Meningkat \\
\hline 15 & Feby Tiana Asy'ari & 57 & 76 & Meningkat \\
\hline 16 & Irma Ronica Sari Ni Luh & 78 & 78 & Tetap \\
\hline 17 & Ivan Venkama S. I Gede & 83 & 88 & Meningkat \\
\hline 18 & Iwan Adhi Putra Kadek & 78 & 78 & Tetap \\
\hline 19 & Junda Artha Indrawan Ketut & 48 & 68 & Meningkat \\
\hline 20 & Linda Fitriani & 70 & 75 & Meningkat \\
\hline 21 & Louis Frangky Jonathan Kune & 68 & 68 & Tetap \\
\hline 22 & Mela Kareri Jovanka & 61 & 78 & Meningkat \\
\hline 23 & Melia Yulanda Cory Putu & 88 & 93 & Meningkat \\
\hline 24 & Merta Dana I Wayan & 46 & 63 & Meningkat \\
\hline 25 & Oktayanti Eka Trisna Dewi Putu & 61 & 73 & Meningkat \\
\hline
\end{tabular}




\begin{tabular}{clccc}
\hline 26 & Prana Isvari Suganda & 74 & 88 & Meningkat \\
27 & Sugih Harta Agung Ngurah Gede & 55 & 75 & Meningkat \\
28 & Surya Buana Artha Gede & 51 & 63 & Meningkat \\
29 & Trisna Wikantari Komang & 68 & 78 & Meningkat \\
& Jumlah & 1.988 & 2.272 & \\
& Rata-rata & 68,6 & 78,3 & \\
\hline
\end{tabular}

Data tersebut menunjukkan bahwa ada peningkatan skor siswa jika dibandingkan dengan pembelajaran menulis teks berita menggunakan model PBL dengan teknik pengamatan objek langsung pada siklus I. Pada siklus I, skor rata-rata siswa adalah 68,6, sedangkan pada siklus II skor rata-rata siswa 78,3. Ini berarti, dengan teknik ini skor menulis teks berita siswa mengalami peningkatan sebesar 9,7\%.

Data di atas juga menunjukan bahwa dari 29 orang siswa terdapat 25 orang siswa mengalami peningkatan hasil belajar menulis teks berita dan terdapat empat orang siswa yang tidak mengalami peningakatan (tetap). Selain hasil tes, hasil angket respon siswa menulis teks berita melalui penerapan model PBL dengan teknik pengamatan objek langsung pada siklus I dan II juga mengalami peningkatan, hal tersebut tergambar dalam tabel berikut.

Tabel 2. Perbandingan Respons Siswa pada Siklus I dan Siklus II

\begin{tabular}{ccc}
\hline Kriteria & Siklus I & Siklus II \\
\hline Sangat Positif & $9(31,04 \%)$ & $16(55,2 \%)$ \\
Positif & $17(58,62 \%)$ & $13(44,8 \%)$ \\
Cukup Positif & $3(10,34 \%)$ & 0 \\
Kurang Positif & 0 & 0 \\
Sangat Kurang Positif & 0 & 0 \\
\hline
\end{tabular}

Jika dibandingkan dengan hasil angket respons siswa pada siklus I dan siklus II, respons siswa mengalami peningkatan sebesar 1,5 pada siklus II.

\section{Simpulan}

Setelah Berdasarkan uraian hasil penelitian dan pembahasan pada bab IV, dapat disimpulkan halhal sebagai berikut. Penerapan model problem based learning dibantu teknik pengamatan objek langsung dapat meningkatkan keterampilan menulis teks berita pada siswa kelas XII MIPA 4 SMA Negeri 2 Singaraja. Pada siklus I, nilai rata-rata keterampilan menulis teks berita siswa sebesar 68,6 . Siswa yang berada pada kriteria sangat baik 2 orang (6,9\%), baik 12 orang $(41,4 \%)$, cukup 11 orang $(37,93 \%)$ dan kurang 4 orang $(13,8 \%)$. Pada siklus II, nilai rata-rata keterampilan menulis teks berita siswa meningkat sebesar 9,7 rata-rata menjadi 78,3 atau berada pada kategori baik. Siswa yang berada pada kriteria sangat baik 5 orang $(17,24 \%)$, baik 20 orang $69 \%$, dan cukup 4 orang $(13,8 \%)$.

Dapat disimpulkan pada siklus II seluruh siswa sudah memenuhi Kriteria Ketuntasan Minimal (KKM) secara klasikal yaitu 93\% melebih target awal yaitu 75\%. Berdasarkan hasil observasi atau pengamatan atas langkah-langkah penerapan model PBL dibantu teknik pengamatan objek langsung untuk meningkatkan keterampilan menulis teks berita siswa kelas XII MIPA 4 SMA Negeri 2 Singaraja menunjukan bahwa diperlukan beberapa modifikasi terhadap langkah-langkah pembelajaran serta kontrol guru dalam penggunaan model serta teknik ini agar hasil yang diharapkan sesuai. Menggunakan model PBL dengan teknik pengamatan objek langsung untuk meningkatkan keterampilan menulis teks berita siswa kelas XII MIPA 4 SMA Negeri 2 Singaraja. Hal ini dibuktikan dengan hasil angket siswa. Pada siklus I, respons siswa tergolong kategori positif dengan skor rata-rata adalah 33,93. Pada siklus II, respons siswa terhadap pembelajaran menulis teks berita meningkat sebesar 1,5 yaitu menjadi 35,41 dan tergolong kategori positif. Hasil angket menunjukkan bahwa siswa kelas XII MIPA 4 memiliki respons yang positif terhadap pembelajaran. Siswa merasa senang mengikuti pembelajaran menulis teks berita dengan menerapkan model PBL dibantu teknik pengamatan objek langsung. 


\section{Daftar Pustaka}

Azwar, S. (2005) Penyusunan Skala Psikologi. Yogyakarta.

Fuad, Z. Al And Helminsyah (2018) 'Anguage Experience Approach Sebuah Pendekatan Dalam Meningkatkan Keterampilan Menulis Siswa Sekolah Dasar', Jurnal Tunas Bangsa, 5(2), Pp. 164-174. Available At: Http://Tunasbangsa.Stkipgetsempena.Ac.Id/Home/Article/Download/78/71.

Ninawati, M. (2019) 'Efektivitas Model Pembelajaran Literasi Kritis Berbasis Pendekatan Konsep Untuk Meningkatkan Keterampilan Menulis Kreatif Siswa Sekolah Dasar', Pendas: Jurnal Ilmiah Pendidikan Dasar, Iv, Pp. 68-78. Doi: 10.23969/Jp.V4i1.1747.

Nisa, K. (2017) 'Kesalahan Penggunaan Bahasa Indonesia Dalam Teks Terjemahan Mahasiswa', Manajemen Asuhan Kebidanan Pada Bayi Dengan Caput Succedaneum Di Rsud Syekh Yusuf Gowa Tahun, 4(1), Pp. 9-15.

Nuryamah, I., Sunarya, D. T. And Irawati, R. (2016) 'Upaya Meningkatkan Keterampilan Menulis Permulaan Dalam Melengkapi Cerita Rumpang Menggunakan Media Gambar Dan Papan Bergaris', Jurnal Pena Ilmiah, 1(1), Pp. 761-770. Doi: 10.17509/Jpi.V1i1.3566.

Puspitasari, E. H. And Rustono, H. B. (2014) 'Peningkatan Keterampilan Menulis Kembali Dengan Bahasa Sendiri Melalui Media Film Dongeng', Jurnal Pendidikan Bahasa Dan Sastra Indonesia, 3(1), Pp. 1-8.

Sholichah, A. S. (2018) 'Teori-Teori Pendidikan Dalam Al-Qur'an', Edukasi Islami : Jurnal Pendidikan Islam, 7(01), P. 23. Doi: 10.30868/Ei.V7i01.209. 